\title{
The Values of Local Wisdom in the Sharing System between Beef Cattle Farmers and Institutions
}

\section{${ }^{1}$ Sitti Nurani Sirajuddin, ${ }^{1}$ Hastang, ${ }^{1}$ Veronica Sri Lestari and ${ }^{2}$ Rosmawaty}

${ }^{1}$ Department of Socio-Economics, Faculty of Animal Husbandry, Hasanuddin University, Makassar, South Sulawesi, Indonesia

${ }^{2}$ Department of Archaeology, Faculty of Cultural Sciences, Hasanuddin University, Makassar, South Sulawesi, Indonesia

Correspondence Author: Sitti Nurani Sirajuddin, Department of Socio-Economics, Faculty of Animal Husbandry, Hasanuddin University, Makassar, South Sulawesi, Indonesia

Telp: +62411-586200

Fax: +62411-585188

E-mail: sitti.nurani@unhas.ac.id

Received date: 19 May 2018, Accepted date: 15 August 2018, Online, Online date: 20 August 2018

Copyright: (c) 2018 Sitti Nurani Sirajuddin et al., This is an open-access article distributed under the terms of the Creative Commons Attribution License, which permits unrestricted use, distribution, and reproduction in any medium, provided the original author and source are cre dited.

\begin{abstract}
A profit sharing system has been recently established between beef cattle farmers at the Hasanuddin Universityas the affiliate or of the Maiwa Breeding Center (MBC) located in Enrekang Regency, South Sulawesi Province, and Indonesia where the profit-sharing system is based on local wisdom. This study aims to find out the values of local wisdom in the management system of the institutions for cutting and institution with institutions. Research was carried out at the Maiwa Breeding Center in June-July 2014 in the districts of Maiwa, Enrekang Regency, Indonesia. The data used were primary data and secondary data. Methods of collecting data were observations and interviews. Data analysis used was descriptive and was distributed with frequency. The results showed the values of local wisdom in the Maiwa Breeding Center system of mutual trust (56.8\%), mutual respect $(22.7 \%)$ and mutual remind $(20,5 \%)$
\end{abstract}

Key words: value, local wisdom, profit system, breeders, institutions

\section{INTRODUCTION}

Development of beef cattle business, agribusiness oriented with partnership pattern is one alternative to increase farmers' profits. [1] explains that partnership is a business strategy carried out by two or more parties within a certain period of time to achieve mutual benefits with the principle of mutual need and mutual nurturing. The patterns that can be applied in partnership are various types including profit sharing system patterns, plasma core patterns, general trade patterns, agency patterns, and franchises. One of the efforts to overcome the problems of farmers in rural areas is the partnership system, among others, with a profit system that aims to increase income by reducing costs incurred between partners. [2] Argues that in rural communities in developing countries, transaction costs are usually low. This can occur because of the closeness of relationships within the community (family, neighbors) so that information about activities in individual communities is widely available and free. This shows that social relations can influence the costs in which social relations have social capital between economic actors. Social capital in transaction activities can be the main basis of sources of economic activity. In the broadest sense, social capital can be the most likely alternative in allocating economic activities efficiently if the market is not able to do it

In theory social capital has an impact on transaction costs. This is evidenced by [3] which discuss the relationship between social capital, transaction costs, and organizational output. In his writings it was found that conflicts in transactions can be solved by the speed of information, the existence of trust and the existence of a strong bond between the two parties. That social capital can reduce transaction costs drastically. The existence of social capital makes small businesses can take advantage of good relations between economic actors and the government as policy makers. Transaction costs according to [4] relate to institutions including profit sharing systems in beef cattle businesses between farmers and institutions

According to [5] the system of collaboration results in the relationships between owners or people who have assets (land, livestock, plants, etc.) with farmers or landfill. The relationship between the businesses is very diverse, especially the traditional results, where very much depends on the agreement of the second agreement. The agreements with the distribution of benefits in the service of the child can be divided as follows: a promise with the delivery of a person to be cared for by certain animals, and sold and fortunate, and promises of livestock and sale and profits, and promises of livestock sold and profits shared.In the resulting system, the agent does not provide the mortgage to the animal (principal). The foundation of the system's power is located in the trust of each party. The loss of trust in one side will establish the system they build [6]. In addition, the partnership system with the results made in the business farms was partly carried out formally well with clients but with the government including with high-ranking teachers. To do the research about the value of local wisdom on the system for the beef cattle farmers with the institution (Maiwa Breeding Center) in the Enrekang Regency, South Sulawesi Province, Indonesia

\section{MATERIALS AND METHODS}


This research was conducted from June to July 2018. The research was conducted in Bangkala Village, Maiwa District, Enrekang Regency, Indonesia. As for location selection because it is the location of the application of the intermediate system between MBC and beef cattle farmers. This type of research is descriptive quantitative.

Samples:

Population is all the smallholder farmers who follow the sharing system with MBC and the sample is 44 smallholder farmers who follow a system of profit sharing with MBC totaling 44 people. The types of data used are quantitative data and qualitative data. The data sources are primary data and secondary data. Methods of data collection are observation and interviews. Data analysis used is descriptive statistics with frequency distribution.

\section{RESULT AND DISCUSSION}

\section{Characteristics Breeders:}

In conducting cattle business, the farmer acts as a decision maker that seeks to make effective and efficient decisions in running and managing his business. The socio economic characteristics of farmers (business scale, number of cattle, age of breeder, level of education, farming experience, number of dependents of the family can influence in making decisions that can give a profit for his business[7].The characteristics breeders who follow the system for results that can be seen in Table 1 .

Table. 1: Characteristics of beef cattle breeders who followed with a MBC sharing system.

\begin{tabular}{|l|l|l|}
\hline Characteristics & Description & MBC Sharing system (percent) \\
\hline \multirow{5}{*}{ Ege } & $0-14$ & 0 \\
\cline { 2 - 3 } & $15-64$ & 95 \\
\cline { 2 - 3 } & 65 & 5 \\
\hline \multirow{5}{*}{ Experience Farming } & Senior High School & 11,4 \\
\cline { 2 - 3 } & Junior High School & 45,5 \\
\cline { 2 - 3 } & Elementary school & 38,6 \\
\cline { 2 - 3 } & No school & 4,5 \\
\hline \multirow{5}{*}{ Number of family members } & $1-4$ & 75 \\
\cline { 2 - 3 } & $5-8$ & 12,5 \\
\cline { 2 - 3 } & $9-12$ & 12,5 \\
\hline Number of livestock ownership & $1-2$ & 18,2 \\
\cline { 2 - 3 } & $3-4$ & 34,1 \\
\cline { 2 - 3 } & $5-6$ & 47,7 \\
\hline & $1-5$ & 66,7 \\
\cline { 2 - 3 } & $6-10$ & 23,07 \\
\cline { 2 - 3 } & More than 10 & 10,26 \\
\hline
\end{tabular}

\section{Source: Primary Data 2018}

Table 1 shows the beef cattle breeders who follow profit share system with institution(15-64 years), which means cattle ranchers have the physical ability in managing beef cattle business, it is in accordance with the opinion of [8] that the age of farmers have a strong influence mainly concerned with the ability to provide food for animals taken from the garden of green fodder were located generally relatively quite far with the location of the maintenance or cage group, in line also with the opinion [9] that the farmers who lived productive typically have a dynamic mindset and excellent physical ability in managing their business. The younger a person's age so the sooner accept a change from the outside because livestock farmers have always wanted to try something new in an effort to increase knowledge and skills in diversifying its business.

For education in beef cattle breeders who follow the system of partnerships with universities profit share system largely at secondary level (45.5\%), suggesting that the cattle breeders profit share system already understand the advantages in following profit share system with MBC.The higher one's education will lead to more advanced one's perspective of things, including the beef cattle business profit share system, it is in accordance with the opinion of [10] that the educational level of farmers will affect patterns of thinking, learning and intellectual level. With the formal and informal education farmer will have extensive knowledge and insight making it easier to respond to an innovation that is beneficial to their business. Also in line with the opinion of [11] that the formal and informal education farmer will have extensive knowledge and insight that will be easier to respond to an innovation that is beneficial to their business. This is also in line with the opinion of [12] that the level of education also affects the increase in income of beef cattle ranchers

Breeder beef cattle farming that do profit share with colleges largely have experience raising in 5-6 years (75\%). Raising experience of respondents strongly affect the conduct of a business, it is appropriate [13] that the experience of raising livestock in effect on how to respond to an innovation. The longer the experience of raising the level of response to a technology will be higher. This is also in line with the opinion of [11] that the cattle breeding experience positively influences the income rising of beef cattle ranchers.

For the number of family members of farmers who perform with college profit share system shows the number of 5-6 people.the number of family members influence in managing a business, this is in line with the opinions [14] and [15] that the number of members of the family farmers can affect business activities because of the number of members of the family farmers can supply manpower availability to assist its activities.

Number of livestock ownership in the system profit share colleges were on a scale of 1-5 (66.7\%),it is appropriate opinion [16] that the livestock business people, among others periodic characterized by small or home businesses. This small scale would cause the population is also low, in line with the statement [17] that the lack of beef cattle population is partly due to the majority of poultry kept by small-scale farmers with limited land and capital. While [18] stated capital is the limiting factor. At this time the level of livestock ownership in relatively small farms that the cow 1-3 tail, goat / sheep 3-5 tail, and the tail of 5-20 birds. Gross revenue of livestock farmers are still not enough to meet the needs of farmers and their families live. Farming is an important additional source of income to sustain the needs of farm families, especially in rural.

\section{Local Wisdom Values in the Sharing System:}

The development paradigm shift from product centered development to people centered development has provided opportunities for independence and local potential as an alternative form of development approach that is relevant for developed. Cultural values can be articulated alone of the driving forces of economy for regional progress. local wisdom in regional planning is the filling and involvement of local resources, because in it there is an estimated base of local knowledge (local knowledge) has developed as a potential planning for local communities within facing regional problems. Local wisdom is all forms of knowledge, beliefs, understanding or insight as well as customs or ethics that guide human behavior in the ecological community. Local wisdom of the local community relates to a system of sustainable resource management and promoting shared ownership, a system of prohibition in over-exploitation, and efforts to maintain the sustainability of ecosystems with local rituals and forms of customary advice that have been inherited in a family[19]. Likewise, the system for the result of the MBC system is the development of a traditional literary system, which is mostly carried out by beef cattle farmers in South Sulawesi Province, Indonesia and the value of local wisdom in the traditional system of mutual trust.

The intermediate system between beef cattle farmers and the Maiwa Breeding Center is a developmental system for the Tesang result system, namely that there is no formal temporary contract for the system to produce with the Maiwa Breeding Center based on a contract agreed between beef cattle farmers and MBC managers. In implementing the system based on local wisdom in the community in the District Maiwa, Enrekang District. [20] said the concept of local wisdom or traditional wisdom or the local knowledge system (indigenous knowledge system) is a typical knowledge that belongs to a particular society or culture that has 
evolved long ago as a result of the process of reciprocal relations between the community and its environment. Thus, the concept of local wisdom systems is rooted in local or traditional systems of knowledge and management. Because of the close relationship with the environment and natural resources, local, traditional, or indigenous communities, through "trials" have developed an understanding of the ecological system in which they live which has been considered retain natural resources, and leave activities that are considered to be damaging to the environment

[21] argue that local wisdom is carried out by certain groups that are local or culturally specific. The actions or actions of certain local communities are traditions that have elements of local expertise that are loaded with values that guide, guide guidance or guidelines for acting and interacting with their environment. Local wisdom is a way of attitudes, perspectives and ways of acting that contain essential wise, intelligent, responsive, cultural value and have high moral integrity and foresight. With local wisdom will explore the cultural scope of local communities oriented to 1) human, natural and cultural balance and harmony, 2) sustainability, natural diversity and culture, 3) conservation of natural resources and ancestral cultural heritage, 4) saving resources economic value, and 5) morality and spirituality [23].As for the values of local wisdom on the system for farmers and farmers managing the Maiwa Breeding Center can be seen in table 2

Table 2: The values of local wisdom in the institutional sharing system (MBC).

\begin{tabular}{|l|l|l|l|}
\hline No & Local wisdom & Frequensi & Percentage \\
\hline 1 & Mutual trust & 25 & 56,8 \\
\hline 2 & Mutual respect & 10 & 22,7 \\
\hline 3 & Mutual remind & 9 & 20,5 \\
\hline & 44 & 100 \\
\hline
\end{tabular}

Table 2 shows the values of local wisdom in the system between farmers and MBC managers, namely mutual trust, mutual respect and mutual remind. The values of local wisdom are in line with the opinion of[22] that local wisdom refers to value in society and natural balance. According to Law No. 32 of 2009 , it provides an understanding of local wisdom, namely the noble values that apply in the community's life system to, among others, protect and manage the environment in a sustainable manner. Values in local wisdom become the main capital in building the community's economy without damaging the social order with the natural environment. The highest percentage of local wisdom values, namely mutual trust, means that beef cattle farmers who do a good system have mutual trust with MBC managers; this is in accordance with [23] opinion the sharing system shows that the value of trust (confidence) and norms have a very important effect on farmers and investors.

Conclusion:

Beef cattle farmers who carry out profit sharing systems at the Maiwa Breeding Center are productive,education at secondary level,experience raising in 5-6 years $(75 \%)$, the number of family were 5-6 people,number of livestock ownership were on a scale of $1-5(66.7 \%)$. The values of local wisdom in the system between farmers and MBC managers, namely mutual trust, mutual respect and mutual remind

\section{REFERENCES}

[1] Haryadi, F.T., 2004. Hubungan Motivasi Beternak Sapi Potongdengan Pendapatan Peternak'.Jurnal Pengembangan Penyuluhan Pertanian, 1( 2): 10-16

[2] Yustika, A.E., 2012. Ekonomi Kelembagaan : Paradigma, Teori, dan Kebijakan.Penerbit Erlangga, Jakarta

[3] Rasyid, T.G., Rohani, M. Aminawar and M. Darwis, 2018. The Level of Social Capital And Its Effect on The Participation ofFarmers on Goat Livestock Business Development In Jeneponto Regency South Sulawesi Province-Indonesia. Advances in Environmental Biology., 12(2): 1-3. DOI: 10.22587/aeb.2018.12.2.1

[4] Sirajuddin, S.N., 2010. Analisis Biaya Transaksi pada Sistem Kemitraan dan Mandiri pada Usaha Sapi Perah di Propinsi Sulawesi Selatan.Disertasi.Institut Pertanian Bogor.

[5] Marwah, 1985. Bagihasil di Hindia Belanda.terjemahan.Yayasan Obor.Indonesia.

[6] Sirajuddin, S.N., A.R. Siregar, S. Nurlaelah, V.S. Lestari and V. Tenrisanna, 2017. The limitation and benefits of partnership sharing system of corporated cattle market(CCM).American-Eurasian Journal of Sustainable Agriculture, 11(1): 11-15.

[7] Hartono, B. and E.S. Rohaeni, 2014. Contribution to income of traditional beef cattlefarmer's households in Tanah Laut regency South Kalimantan Indonesia.Livest Res Rur Dev., 26.

[8] Jeremias, J.A., D.R. Tulle, C. Leo Penu dan I.G.N. Jelantik, 2017. Tingkat Pendapatan Peternak pada Penggemukan Sapi Bali dengan Sistem Bagi Hasil di Kabupaten Kupang.Jurnal Partner. Nomor 1.hal:43-50.

[9] Murwanto, A.G., 2008. Karakteristikpeternakdantingkatmasukanteknologipeternakansapipotong di lembahprafikabupatenmanokwari. Jurnalilmu peternakan, 3(1): 8-15.

[10] Mubyarto,1986. Pengantar ekonomipertanian.Lembagapenelitian, pendidikandanpenerapanekonomi.Jakarta

[11] Mahmud, A., 2013. Analisis dayasaingdanstrategipengembanganpeternakansapipotong di propinsi Sulawesi selatan.Disertasi.Institutpertanian Bogor.

[12] Hasnudi, I.S., A.H. Berutu, Daulay, N. Ginting and I. Sembiring, 2018. Analysis of cattle breeder's income in South Kualuh sub-district of Labuan Batu Utara Regency.IOPConf.Series: Earth and Enviromental Science, 122:1-6

[13] Mastuti dan Hidayat, 2008.Perana tenaga kerja perempuan dalam usaha ternak sapi perah di Kabupaten Banyumas.Fakultas Peternakan Universitas Jenderal Soedirman.Purwokerto

[14] Sonbait, L.Y. Santosa, K. Adan Panjono, 2011. Evaluasi program pengembangansapipotonggaduhanmelaluikelompoklembagamandiri yang mengakar di masyarakat di KabupatenManokawari Papua barat.Buletin Peternakan, 35(3): 208-217.

[15] Rahmah, U.I.L., 2014. HubunganAntarakaraktersitikdenganresponpeternakterhadapintroduksiTeknologiInseminasiBuatan(IB) padaternakdomba. JurnalIlmudanPeternakan.2 (2):1:12

[16] Cyrilla and Ismail, 1988. Usaha Peternakan. Diktat Kuliah. JurusanSosialEkonomi. FakultasPeternakan. InstitutPertanian Bogor, Bogor.

[17] Kariyasa, K. 2005. Sistemintegrasitanaman-ternakdalamperspektifreorientasikebijakansubsidipupukdanpeningkatanpendapatanpetani.Jurnal AnalisisKebijakanPertanian3(1):68-80.

[18] Kusnadi, U., 2008. Inovasiteknologipeternakandalam sub system integrasitanaman- ternakuntukmenunjangswasembadadagingsapi. Pengembanganinovasi pertanian, 1(3): 189-205. PusatPenelitiandanPengembanganPeternakan.Bogor

[19] Asriani, A., 2017. Kearifan Lokal dalam Pemeliharaan Kerbau Lokal di desa Randan Batu Kabupaten Tana Toraja.BuletinNutrisidanmakananTernak, 12(2) : 64-72.

[20] Saam, Z., danArlizon, 2011.KearifanLokalDalamBudayaPekandangandi KabupatenKuantanSingingi.JurnalIlmuLingkungan. 5(1) : 10- 20.

[21] Elizabeth, R., 2007. Reorientasi dan Peran Kearifan Lokal dalam Akselerasi Inovasi system Integrasi TanamanTernak Mendukung Ketahanan Pangan di Pedesaaan. Seminar Nasional Dukungan Teknologi untuk Meningkatkan Produk Pangan Hewani dalam rangka Pemenuhan Gizi Masyarakat. Pusat Analisis Sosial Ekonomi dan Kebijakan. Bogor.

[22] Sutikno dan Hakim, 2015. Budaya masyarakat dan partisipasi koperasi terhadap pembangunan lingkungan masyarakat lokal di kabupaten Pasuruan

[23] Sirajuddin, S.N., S. Nurlaelah, A. Amrawaty, Amrullah T. St. Rohani, I.M. Saleh, 2017. Relationship Between Farmers Characteristic and Income from Beef Cattle with The Traditional Profit-Sharing.American Eurasian Journal of Agriculture, 11(5): 29-34. 